Review of

ECONOMICS

and

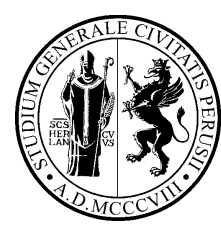

www.rei.unipg.it

\title{
Ownership Structure and Literacy: Evidence Across Spanish Districts in Late 19th Century
}

\author{
Alberto Basso ${ }^{\bowtie}$ \\ PBS \\ University of Plymouth
}

\begin{abstract}
This paper studies the association between ownership structure and literacy across Spanish districts in the late 19th century. We find a positive correlation between the ownership rate of the type of livestock mostly used in agriculture (i.e. cattle) and the literacy rate, which is robust to controlling for a large set of factors including spatial correlation. We observe a similar association also for the second type of livestock mostly used in agriculture (i.e. mules). This result suggests that the structure of livestock ownership, which is used as a proxy for land ownership, played a role in shaping literacy rates. We use a province-level analysis to assess the importance of demand and supply channels in determining this correlation.
\end{abstract}

JEL classification: 015; 043; N33;

Keywords: ownership, education, Spain

I thank two anonymous referees and Stylianos Michalopoulos for helpful comments and suggestions. All errors are mine.

Address: PBS, University of Plymouth, Cookworthy Building, Drake Circus, Plymouth, PL4 8AA, UK. (Phone: +441752585621. Email: alberto.basso@plymouth.ac.uk).

\section{Recommended Citation}

Basso, A. (2014). Ownership Structure and Literacy: Evidence Across Spanish Districts in Late 19th Century. Review of Economics and Institutions, 5(2), Article 4. doi: 10.5202/rei.v5i2.121. Retrieved from http://www.rei.unipg.it/rei/article/view/121 


\section{Introduction}

One of the first steps in implementing a national system of primary education in Spain was the introduction of the Ley Moyano of 1857. This established compulsory schooling attendance for children aged between 6 and 9 years, that could be voluntarily extended to the age of 12. However during the second half of the 19th century school attendance was relatively low on average in Spain, especially compared to other European countries ${ }^{1}$

This paper studies the role of the ownership structure in shaping literacy rates across Spanish districts in the late 19th century. The main aim of the paper is to provide a quantitative assessment of the association between the ownership rate of the type of livestock most used in agriculture and educational levels. Demand side factors might have been more relevant than supply side factors in explaining variations in literacy rates across Spain in the late 19th century. Nuñez (2005b) suggests that peasant owners had a higher demand for schooling than landless day-labourers because of higher expected returns related to, for example, reduced transaction costs. Hence, being a landowner - independently of the size of the property - would increase the incentives to acquire skills such as literacy in order to be able to understand and deal with (land ownership) contracts and related matters. Our measure of ownership rate aims at capturing this element of heterogeneity: that is, the presence of a relatively large number of land owners compared to landless individuals. Following the argument of Nuñez (2005b), in areas where landownership was more common, the incentives to acquire education, at least in the form of literacy, should have been higher. To test whether the demand for education was actually higher in areas where (land) ownership was more diffused, we look at the association between literacy rates of adult men and the ownership rate. ${ }^{2}$ As an additional test we also check whether a similar relationship emerges when using a measure for the supply of schooling services. ${ }^{3}$

A strand of the recent literature has focused on analysing one supply

1 According to Morrisson and Murtin (2009), average years of schooling in the adult population in Spain in 1900 were 4.51. These are lower compared to other western European countries: 6.63 in France, 6.36 in Germany and 5.83 in the United Kingdom.

2 In our analysis we use specific types of livestock owners as a proxy for land ownership.

${ }^{3}$ Where the demand for education was higher, local politicians should have implemented policies aimed at matching the supply of schooling to its demand. We exploit the fact that throughout the 19th century the system of financing for public primary school was decentralised (Nuñez 2005a). Since the burden of funding schools fell on local authorities, local politicians could have had a relevant role in the decision to allocate resources to education. According to Pidal and Rosés (2011) historical evidence suggests that landowners used their local power to influence policy decisions in Spain. Hence, where ownership was more diffuse and peasants counted for a larger share of the population, politicians would have higher incentives to support education in order to respond to the needs of local citizens. To test this hypothesis we use as a measure of local support to education, the number of teachers per child. 
side channel. Specifically, this refers to the negative effect on education expansion due to the presence of large land owners. That is, as human capital is not complementary to land in production, large land owners do not perceive any advantage by promoting schooling (Galor et al. 2009), and thus try to constrain the supply of education. Recent empirical studies tend to confirm the relevance of this channel (Cinnirella and Hornung 2013; Hippe and Baten 2012).

The main contribution of this paper is to provide evidence of a complementary demand side mechanism, through which the ownership rate, rather than the share of large land owners, played a role in shaping literacy rates. Using men's literacy as a measure of educational attainment, we provide evidence of a robust positive correlation between literacy and local ownership rates. In this district level analysis, we cannot explicitly differentiate between demand and supply channels: hence the correlation we find between ownership and literacy rates might reflect an effect running through both channels. Using a province-level analysis, we run a horse-race which suggests that the demand-side channel might be more relevant.

The paper is structured as follows. Section 2 reviews the related literature. Section 3 describes the data and the empirical strategy. Section 4 displays the results of the district-level analysis while Section 5 exploits province-level data. Finally, Section 6 concludes.

\section{Related Literature}

Identifying the role of institutions is crucial to shedding light on differences in development across space. A vast literature has analysed this issue adopting different strategies (e.g. Acemoglu et al. 2001; Easterly and Levine 2003; Michalopoulos and Papaioannou 2013, 2014).

The work of Engerman and Sokoloff forms part of this literature (e.g. Engerman and Sokoloff 2000). Their main argument is that geography has a long-lasting impact on development through its effect on institutions. Focusing on the different development paths of South-Central and North America, they suggest that different geographical endowments, such as the type of crops most suitable for cultivation, affected the land ownership structure that endogenously arose in different geographical areas. Specifically, certain endowments would favour large scale exploitation (in the presence of economies of scale), thus leading to the creation of large plantations and landed properties. This would lead to the formation of institutions protecting these large landowning elite, and consequently against growth-enhancing policies such as those promoting education.

Several empirical investigations of the channel linking geography, ownership structure, institutions and development have been carried out. Among these, Easterly and Levine (2003) find evidence that endowments (measured in terms of tropics, germs, and crops) affect development through in- 
stitutions. Easterly (2007) provide further cross-country evidence in favour of the Engerman-Sokoloff argument by showing first that agricultural endowments determines inequality and that the latter determines development. Other geographical and climatic characteristics might have had a similar impact. Acemoglu et al. (2001) argue that geographical and climatic conditions were crucial in determining historical institutions developed by European colonizers. Where settler mortality was higher, colonizers developed extracting institutions while where they found favourable conditions they settled in large numbers and developed growth-enhancing institutions.

However, one of the main issues faced by cross-country empirical investigations of the role of historical factors in fostering economic development is the difficulty in accounting for other cross-country heterogeneity that might be responsible for different development paths. A way to partially solve this issue is to focus on more homogeneous geographical areas: one possibility is to exploit within-country differences.

Recent studies have focused on the role of the ownership structure, suggesting that historical inequality in land ownership was among the main determinants of the level of support to education expansion. According to Galor et al. (2009) inequality in the distribution of landownership delays the implementation of human-capital promoting institutions. This would happen because large landowners would not gain from the accumulation of human capital since the latter is not complementary to land in production. The authors test this hypothesis using state-level data for the United States and find that education expenditures across states over the period 1900-1940 were negatively affected by land inequality. Focusing on Prussia and using several cross-sections during the 19th century, Cinnirella and Hornung (2013) analyse specifically the effect of landownership concentration on school enrolment. Finally, using a large data set on regional numeracy in 19th century Europe, Hippe and Baten (2012) find a negative correlation between land inequality and numeracy, especially in less industrialised countries.

\section{Data and Empirical Strategy}

\subsection{Data}

To measure ownership rates we use indices computed combining data from the livestock census (Censo de Ganaderia) for the year 1865 and the population census of 1860 . Literacy rates and most control variables are taken from the population census of 1887 . The data we use in our main empirical analysis is measured at the district-level. ${ }^{4}$ Because of changes in administrative borders in this period of time, our sample (see Appendix) consists

\footnotetext{
${ }^{4}$ Censuses are available at www.ine.es.
} 
only of those districts that were not affected by such changes, that is those formed by the same municipalities in 1860 and 1887. We take into account municipalities that just changed their name and mergers between municipalities within the same district $:^{5}$

The Censo de Ganaderia of 1865 provides information on the number of owners of different types of livestock. Information about the size of livestock ownership is not available at the district-level, whereas it is available at the province level. In Section 5 we exploit the province-level data to show two main things. First, that livestock (ownership) inequality is a good proxy for land (ownership) inequality, thus suggesting that livestock ownership can be used as a proxy for land ownership. ${ }^{6}$ Second, that across Spanish provinces the (positive) correlation between literacy and ownership rates is stronger and more robust than the (negative) correlation between literacy rates and ownership inequality. The livestock census also provides the allocation of each type of livestock according to the task it was assigned. Overall there are five possible destinations: consumption, agricultural work, movement of machinery, transportation and reproduction (including production of dairy products, etc.).

Among all types of livestock the ones that were assigned to agricultural tasks are the following: cattle (cows, oxen), mules, horses and donkeys. By analysing the distribution across Spain, two main features characterised the allocation of these types of livestock according to the above tasks (Table 1). First, the livestock that, within its type, is used mostly in agriculture is the mule, followed by donkeys, cattle and horses. Second, by looking only at the number of animals used in agriculture, the most used is cattle, followed by mules, donkeys and horses. We use various indices as measures of ownership rates. One index is the ratio between the average number of livestock owners (of cattle, mules, donkeys and horses) in 1865 and the number of adult men in 1860 (labelled Ownership rate). The other indices are constructed in a similar way but one for each type of livestock, so to get four different measures of ownership rates. Our preferred measure is the ownership rate of cattle, since this is the type of livestock that is mostly used in agriculture: hence it should be a good proxy for the share of land owners. Where there are few cattle owners relatively to adult men, landless individuals should count for a relatively large fraction of the working population. On the other hand where cattle ownership is more diffuse, we should observe a relatively large number of land owners.7 In our analysis we also

5 To account for this we use information from Ministerio de Administraciones Públicas (2008). We drop approximately 100 districts, while our sample consists of 374 units. Testing for any statistical difference in average men's literacy - measured in 1887 - between the selected and unselected districts, we cannot reject the null hypothesis of no statistical difference between the two samples.

6 The measures of ownership inequality we use are the shares of medium-large livestock owners and the Gini index.

7 Unfortunately, to our knowledge, no data on land ownership is available for Spain in 
Table 1 - Livestock Census of 1865

\begin{tabular}{|c|c|c|c|c|c|}
\hline $\begin{array}{l}\text { Distribution of each } \\
\text { type across activities }\end{array}$ & Consumption & Agriculture & Machines & Transport & Reproduction \\
\hline Cattle & 0.07 & 0.56 & 0 & 0.03 & 0.34 \\
\hline Mules & 0 & 0.62 & 0.01 & 0.26 & 0.1 \\
\hline Donkeys & 0 & 0.48 & 0 & 0.37 & 0.14 \\
\hline Horses & 0 & 0.35 & 0.01 & 0.31 & 0.33 \\
\hline $\begin{array}{l}\text { Distribution of each } \\
\text { type in agriculture }\end{array}$ & Cattle & Mules & Donkeys & Horses & \\
\hline Agriculture & 0.43 & 0.27 & 0.23 & 0.07 & \\
\hline Ownership size & Cattle & Mules & Donkeys & Horses & \\
\hline Per owner, average & 4.8 & 1.9 & 1.4 & 1.8 & \\
\hline
\end{tabular}

Figure 1 - Men's Literacy in 1887

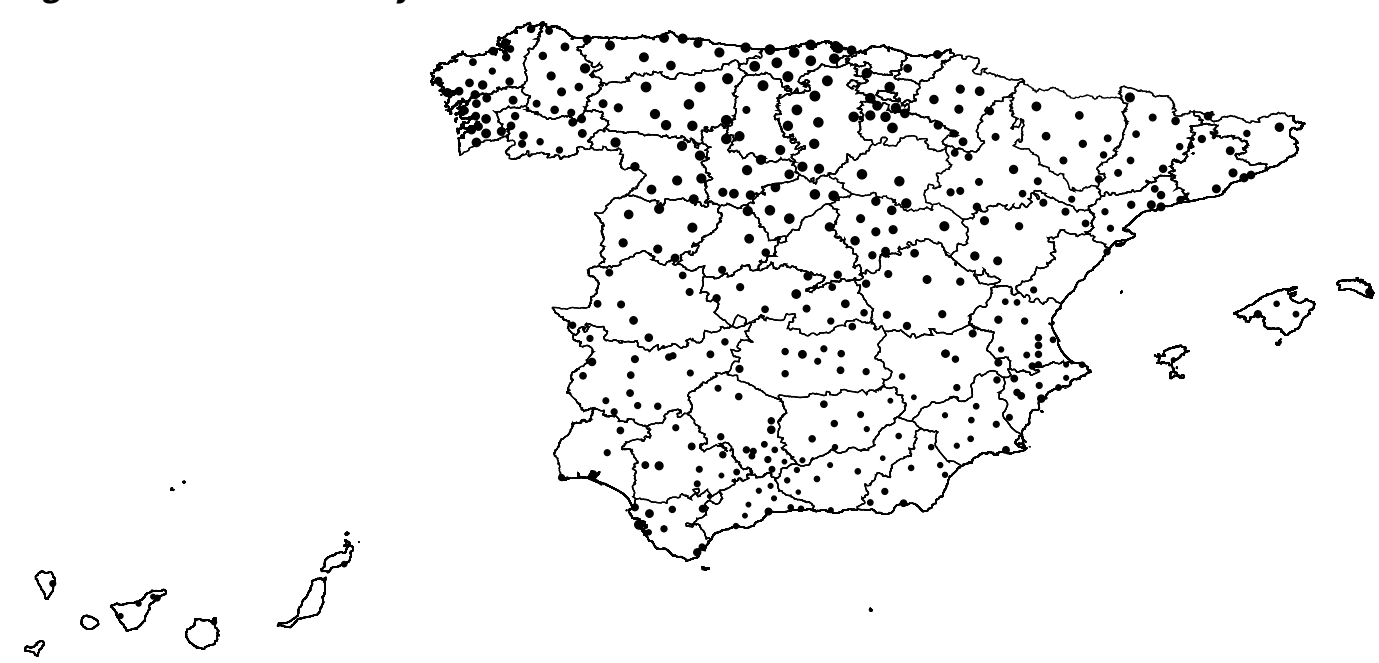

Note: Larger Dots Stand for Higher Literacy Levels

include ownership rates of other types of livestock to allow for the possibility that these other types act as substitutes for cattle in agricultural work. To assess the association between ownership rates and education, we use as a measure of educational attainment - literacy rates for men aged 21-40 in 1887.8 Figures 1 and 2 show the levels of men's literacy and ownership rates across Spain for the districts in our sample.

We control for several factors that might be important in explaining dif-

the late 19th century. Data on land ownership is available for 27 (out of 49) provinces in 1924. We use these data to check whether livestock ownership is a good proxy for land ownership.

8 We choose to use men's literacy because it should depend to a lower extent - compared to women's education - on cultural factors, the latter being particularly difficult to account for in a cross-section. 
Figure 2 - Ownership in Late 19th Century

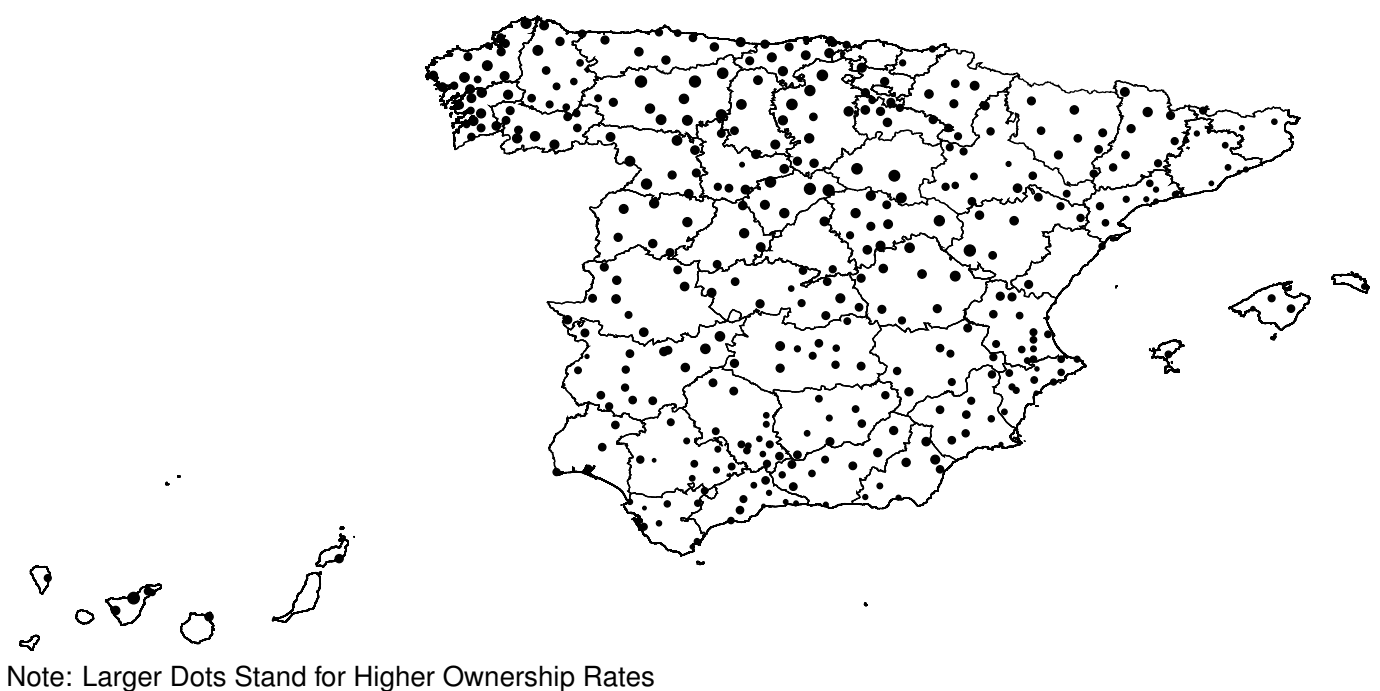

ferent literacy rates across districts, all measured in 1887. The dependence on agriculture is captured by the share of men aged 21-40 working in the primary sector. The development of the industrial sector is measured by the share of adult men aged 21-40 that work in industry, where the latter includes manufacturing and mining. 9 As a proxy for the urban environment we use the fraction of individuals living in towns with more than 20000 inhabitants and in the capital city of each province. In addition we use a dummy variable that takes value one for districts where the capital of each province is located. This would control for the role of administrative and public jobs opportunities on stimulating the demand for human capital (at least in terms of literacy and numeracy) and consequently school attendance. We use a measure of temporary men's migration to capture the role of work-related seasonal migration: following Becker et al. (2010) this is defined as the difference between married males and married females, divided by married females.

We also control for the latitude and longitude of (the main city of) each district. Latitude and longitude are two exogenous measures that are correlated with geographical and climatic conditions, which affect agricultural productivity. Since agriculture was the main economic activity in the historical period under analysis ( $74 \%$ of adult men were employed in agriculture in our sample), their inclusion helps to capture not only differences in agricultural productivity but also in income. Province dummies are used to

\footnotetext{
9 The disaggregation available regarding occupations does not allow to distinguish between manufacturing and mining. Transportation and trade sectors are not included in industry. Due to the definition of industry some districts (precisely 16) are characterised by 0 shares. Very low shares of industrial employment should identify extremely rural environments: of course this depends to some extent on the definition of the industry sector, but it is in line with the low industrial development that characterised Spain in 1887 (the average share in industry in our sample is 0.02 ).
} 
control for fixed province-level characteristics. Finally, to account for spatial correlation we include a spatially lagged dependent variable (spatial lag model) or a spatial error component (spatial error model).

Table 2 displays the variables and their sources. Table 3 includes some descriptive statistics that characterize the sample. Table 4 shows pairwise correlations between the main variables.

\section{Table 2 - Main Variables and Data Sources}

Share of literate men (21-40)

Livestock ownership rates

Share in agriculture, men (21-40)

Share in industry, men (21-40)

Share urban

Temporary men's migration

Teachers per child (6-15)

Latitude and longitude
Author's computation using population census (1887)

Author's computation using livestock census (1865) and population census (1860).

Author's computation using population census (1887)

Author's computation using population census (1887)

Author's computation using population census (1887)

Author's computation using population census (1887)

Author's computation using population census (1887)

http:/ / www.businessintelligence.info/docs

/listado-longitud-latitud-municipios-espana.xls

Table 3 - Descriptive Statistics: District Level Data

\begin{tabular}{lcccc}
\hline & Mean & Std. dev. & Min & Max \\
\hline Population & 34846.82 & 18640.79 & 7410 & 184070 \\
Share of literate men (aged 21-40) & 0.50 & 0.19 & 0.17 & 0.95 \\
Ownership rate & 0.16 & 0.06 & 0 & 0.39 \\
Ownership rate (cattle) & 0.19 & 0.23 & 0 & 0.91 \\
Ownership rate (mules) & 0.14 & 0.10 & 0 & 0.56 \\
Ownership rate (horses) & 0.09 & 0.06 & 0 & 0.42 \\
Ownership rate (donkeys) & 0.23 & 0.14 & 0 & 0.61 \\
Share in agriculture, men (aged 21-40) & 0.74 & 0.13 & 0.19 & 0.93 \\
Share in industry, men (aged 21-40) & 0.02 & 0.03 & 0 & 0.25 \\
Share urban & 0.08 & 0.22 & 0 & 1 \\
Temporary men's migration & 0 & 0.23 & -0.3 & 4.37 \\
Teachers per child (aged 6-15) & 0.01 & 0.00 & 0.00 & 0.03 \\
\hline Note: data on 374 Spanish districts in late 19th century. & & &
\end{tabular}




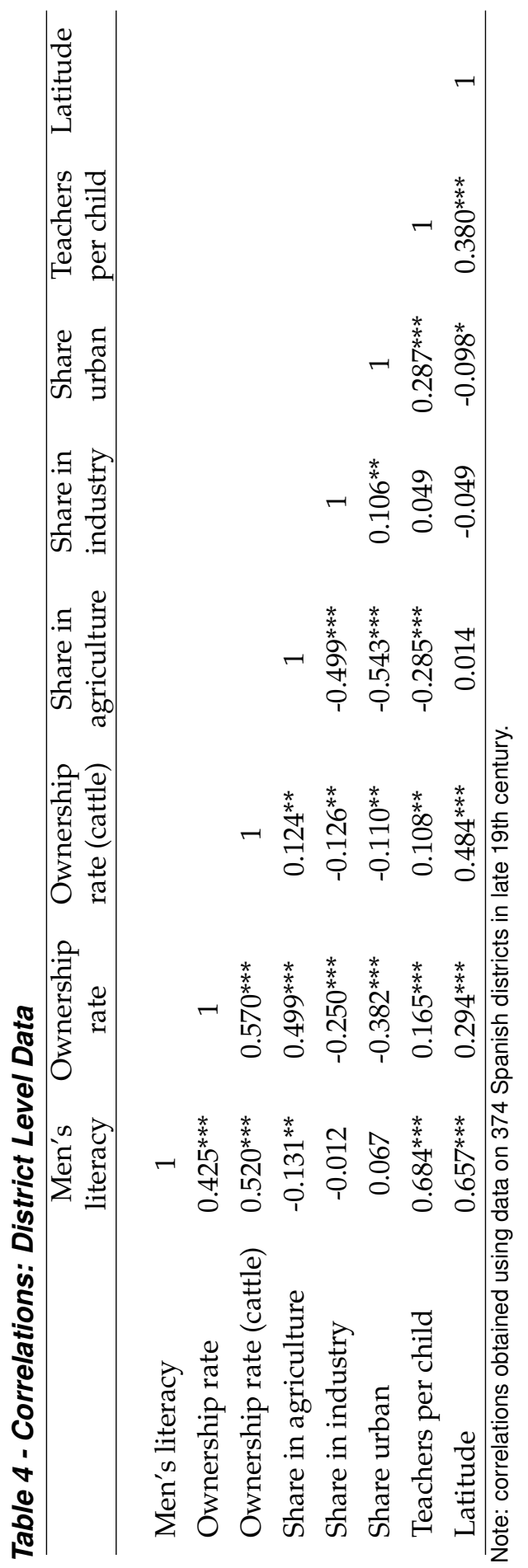




\subsection{Empirical Strategy}

The association between literacy and ownership rates is characterised as follows:

$$
\text { educ }=\text { own rate } \gamma_{1}+X \gamma_{2}+\psi
$$

where $e d u c$ is the share of literate men (aged 21-40) in each district, own rate is our measure of (livestock) ownership rates in each district and $X$ includes district-level control variables. We show that the correlation between the ownership rate of the type of livestock mostly used in agriculture and literacy rates is robust to the inclusion of a large set of factors that are important in explaining educational levels. Given the available data, we cannot identify a variable that could be used - in an instrumental variable strategy - as a valid instrument for ownership rates. Hence, our analysis is to be interpreted as providing evidence of a robust association (i.e. conditional correlation) between ownership and literacy rates. To account for spatial correlation, we estimate spatial lag and error models. 10

The spatial lag model is defined as follows:

$$
\text { educ }=\rho W e d u c+\text { own rate } \gamma_{1}+X \gamma_{2}+\psi
$$

where $\mathrm{W}$ is the spatial weight matrix and Weduc is the spatially lagged dependent variable ${ }^{11}$ term:

Instead the spatial error model includes a spatial component in the error

$$
\text { educ }=\text { own rate } \gamma_{1}+X \gamma_{2}+\mu \quad \mu=\lambda W \mu+\epsilon
$$

where $\mathrm{W} \mu$ is the spatially lagged error term.

\footnotetext{
${ }^{10}$ Spatial lag and error models are estimated using the STATA command spmlreg (Jeanty 2010).

11 The inverse distance spatial weights matrix is computed using latitude and longitude of the main city of each district.
} 


\section{Ownership and Literacy Rates: Empirical Evi- dence}

\subsection{Ownership and Literacy Rates: OLS}

We start our analysis by looking at the association between our general measure of ownership rates and men's literacy across Spanish districts in the late 19th century. As mentioned above our aim is to show that the correlation between ownership and literacy rates is robust to the inclusion of a large set of relevant regressors. Table 5 displays the results from estimating Equation 1 by OLS. We progressively include several control variables to capture forces relevant in shaping educational attainments. Among these we include the dependence on agriculture and the development of the industrial sector: the former displays the expected negative and significant correlation with literacy while the latter does not show any significant association with education. 12 Urbanization and hosting the capital of a province is positively associated to literacy while areas where men's temporary migration is higher tend to have lower levels of education. Geographical controls - latitude and longitude - are significantly related to literacy rates, with Northern and Western areas displaying higher literacy levels. We notice that across all specifications there is a positive association between ownership and literacy rates: this suggests that where there were many livestock (land) owners relatively to adult men, demand for education tended to be higher. Table 6 presents a similar exercise to that carried out in Table 5, but distinguishing four different measures (one for each type of livestock) of ownership rates. First, we notice that by using these disaggregated measures, the explanatory power of the regressions increases. Second, for three types of livestock (cattle, mules, and horses) the positive conditional correlation with literacy rates is strong and significant in all specifications. Table 7 presents alternative specifications that also include province dummies. These help to control for some of the spatial correlation and are important to control for fixed province-level characteristics. The main conclusion we draw is that the ownership rate of cattle, the type of livestock mostly associ-

12 The average share of men employed in industry in our sample is 0.02 . This reflects an extremely low industrial development. Further, mining - which is included in industry is not likely to increase the demand for education (we cannot distinguish between manufacturing and mining). Also, in the first stage of industrialization, an eventual increase in child labour would tend to reduce school attendance: for example, Camps (2003) argues that this was the case in Catalonia. This is a possible explanation for the negative but not significant correlation with literacy that we find in our sample. An increase in education due to higher technological progress and returns to human capital would be a complementary mechanism to the one we explore here, but it's likely to have played a more important role later on. In fact, Spain experienced the onset of the fertility transition and a broad reformation of the schooling system in the first two decades of the 20th century. 
ated with agricultural work, is robust to the inclusion of province dummies. Other things equal, a one-standard-deviation-increase in the ownership rate of cattle is associated on average with a 0.034 increase in the literacy rate (Table 7 , column 6). The ownership rate of mules, the second most used type in agriculture, also displays a positive and significant correlation, with the exception of the case in which standard errors are clustered at the provincelevel. We now proceed by estimating spatial lag and error models to fully account for the presence of spatial correlation.

\subsection{Controlling for Spatial Correlation}

Literacy might be also driven by a diffusion process, where the spread of new attitudes towards schooling could play an important role. Hence, after the introduction of compulsory schooling in 1857, the willingness to invest in education might have gone through a process of adaptation. We proceed by estimating spatial lag (Equation 2) and error (Equation 3) models (Table 8) 13 Among the two, the spatial error model seems more appropriate in this context. This is because the spread of cultural attitudes towards education is omitted in our empirical model, not education itself ${ }^{14}$ The inclusion of a spatially lagged dependent variable does not alter our previous results (Columns 1-4). The ownership rate of the type of livestock mostly used in agriculture (i.e. cattle) is significantly and positively correlated with literacy. The ownership rate of mules is also positive and significant in all specifications. We obtain similar results by estimating spatial error models (Columns 5-8). The ownership rates of cattle, mules and horses are significantly and positively associated to literacy rates. When including province dummies (Columns 6 and 8) the spatial error component $(\lambda)$ is no longer significant, suggesting some redundancy between the two. ${ }^{15}$ The spatial components ( $\rho$ and $\lambda$ ) are positive and significant in six out of eight specifications, confirming the appropriateness of their inclusion.

\footnotetext{
${ }^{13}$ Spatial lag and error models are estimated via MLE. Similar results (not reported here) are obtained using OLS.

${ }^{14}$ For completeness we include also the spatial lag model.

${ }^{15}$ We prefer to use spatial error and lag components to capture spatial correlation because it seems more reasonable to assume the existence of stronger spatial effects between districts across a border (i.e. contiguous but belonging to different provinces) rather than between districts relatively far away but belonging to the same province. The former are ignored by province dummies.
} 


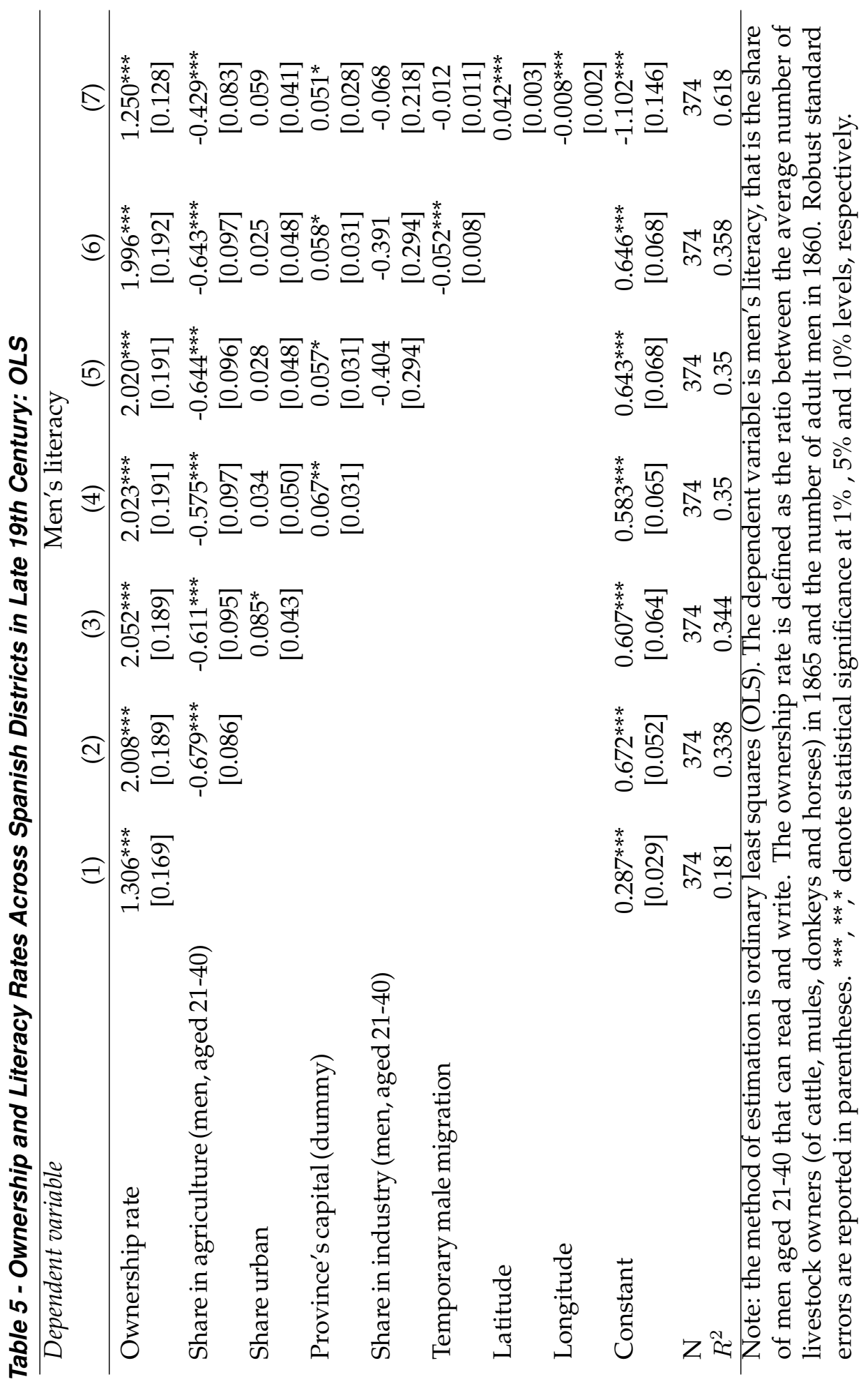




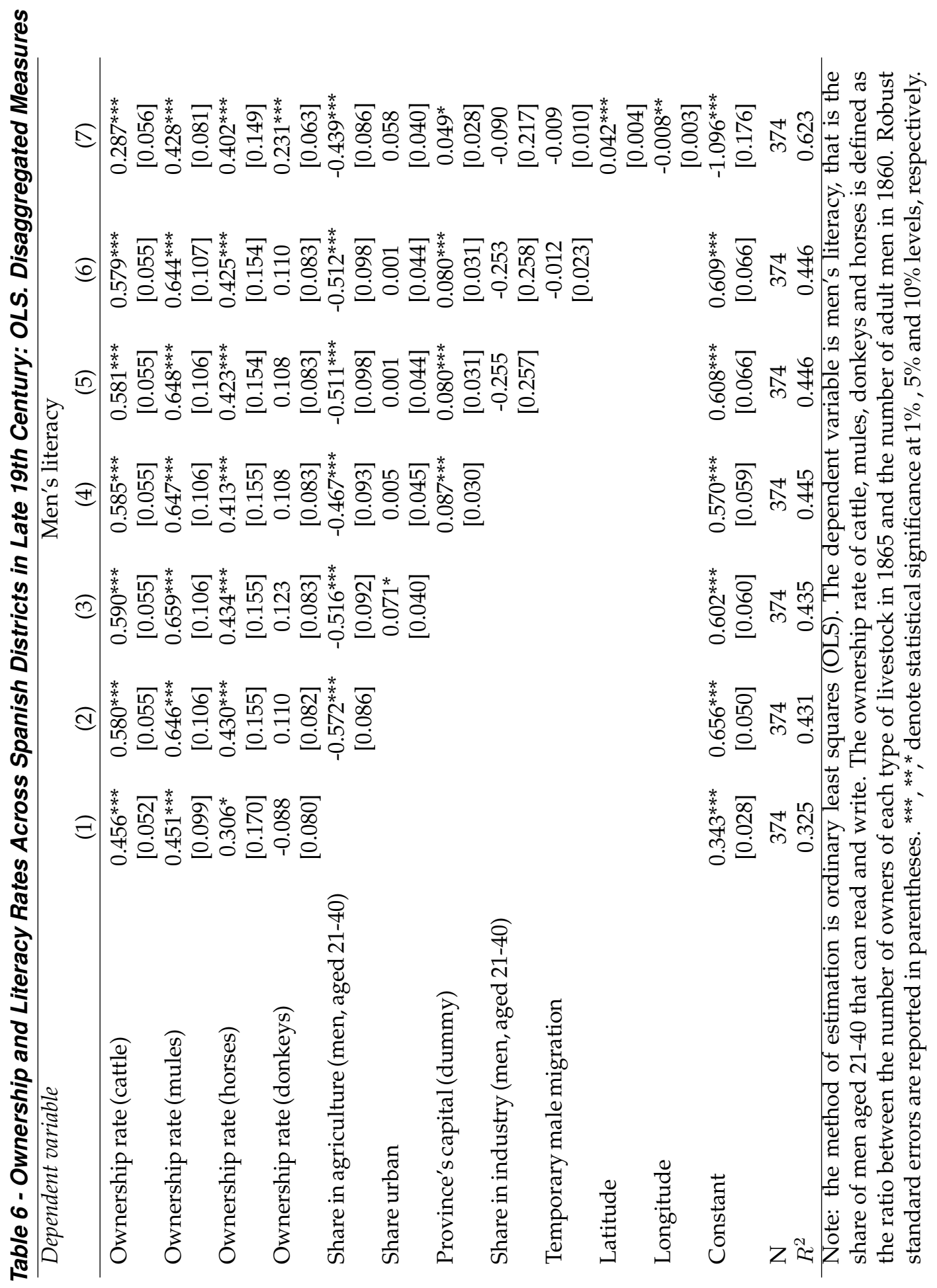




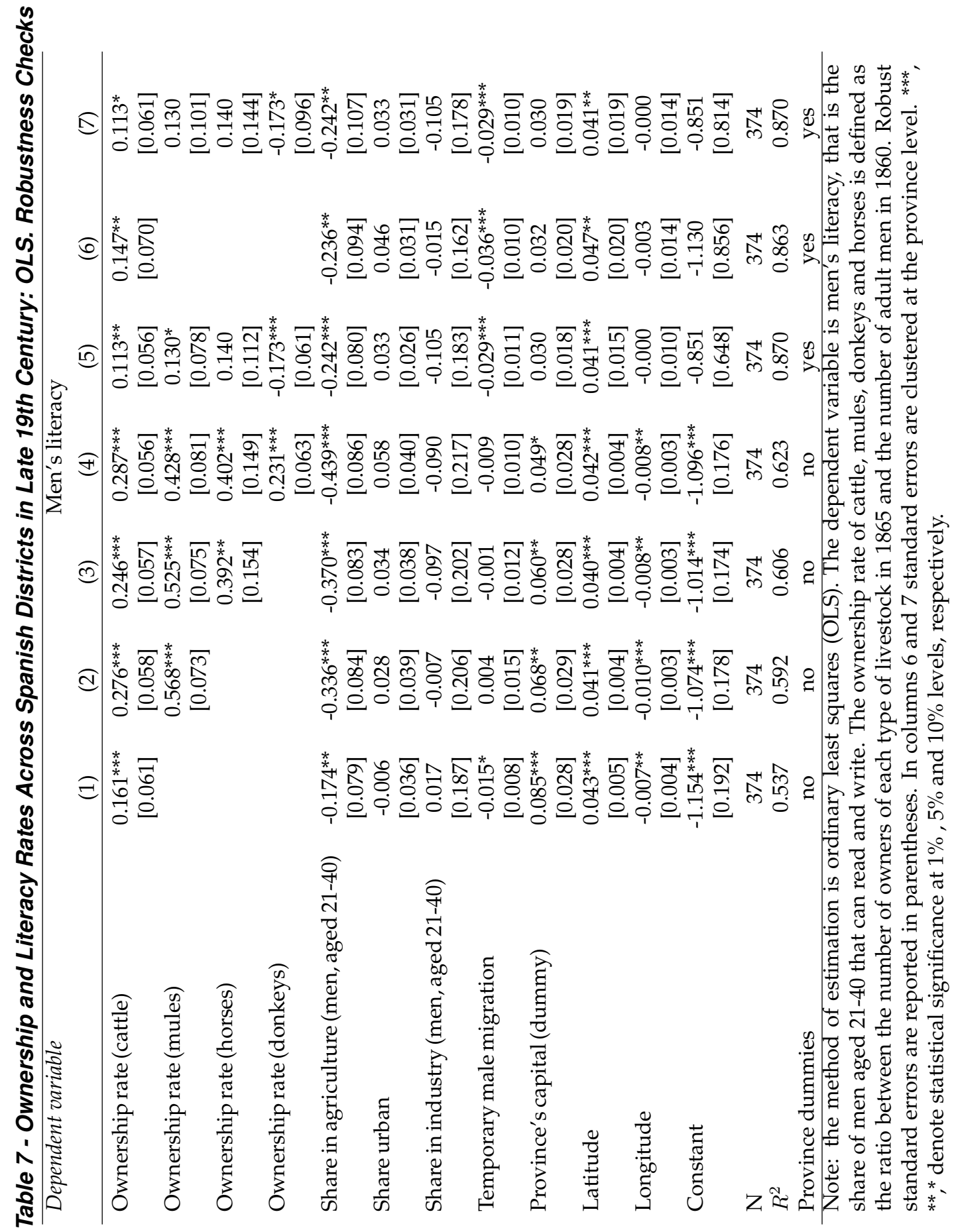




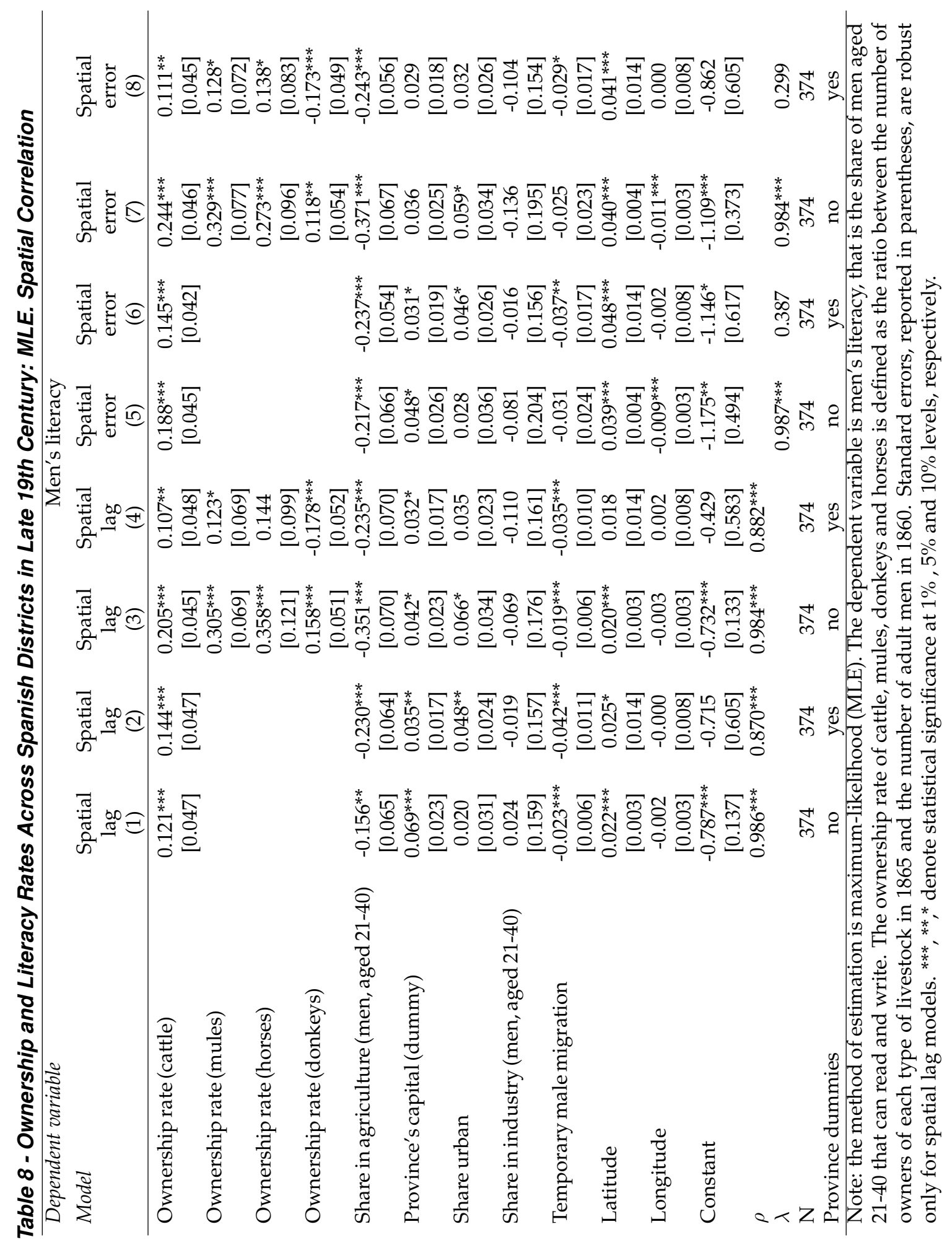




\subsection{Ownership Rate and Local Support to Education}

As supply of schooling services should match the demand for education, we test whether the ownership rate is positively associated with a measure of local support to education, that is, the number of teachers per child ${ }^{16}$ Estimation results are reported in Table 9 which includes the baseline model together with the spatial lag and error models, all including province dummies.

Overall we notice that the ownership rate of the type of livestock mostly used in agriculture (i.e. cattle) is positively related to our measure of local support to education across all specifications. Other things equal, a onestandard-deviation-increase in ownership rate of cattle is on average associated with a 0.001 increase in the number of teachers per child (Table 9, Column 2). Similarly to Table 8 , the inclusion of the province dummies together with the spatial error component seems redundant: for example Column 8 where $\lambda$ turns negative and significant.

\section{Province-Level Analysis}

In this section we provide some supportive evidence that a demand channel might be more relevant - to explain the correlation that we have documented - than the supply side channel highlighted by the recent literature. We exploit province-level data to support two claims. First, we provide evidence that livestock (ownership) inequality is a good proxy for land (ownership) inequality, thus suggesting that livestock ownership can be used as a proxy for land ownership. Second, we show that across Spanish provinces the positive correlation between ownership and literacy rates is stronger and more robust than the negative correlation between ownership inequality and literacy rates. ${ }^{17}$ In order to check whether livestock inequality is a good proxy for land inequality, we look at the correlation between the share of medium-large livestock owners in 1865 and the share of mediumlarge land owners in 1924 for 27 (out of 49) provinces.

\footnotetext{
${ }^{16}$ Supply and demand of schooling would tend in general to equilibrium. However, in this historical context we can expect discrepancies at given points in time between the supply and the demand sides. Further, individuals willing to learn how to read and write, in the absence of formal schools, might do so with the help, for example, of other literate family members.

${ }^{17}$ Inequality in livestock ownership is measured with the Gini index and alternative specifications of the share of medium-large livestock owners. Since we have information on the number of livestock owners for different ranges of ownership (e.g. number of owners of 3 to 5 heads), in computing the Gini Index we assume that owners within each range are uniformly distributed.
} 


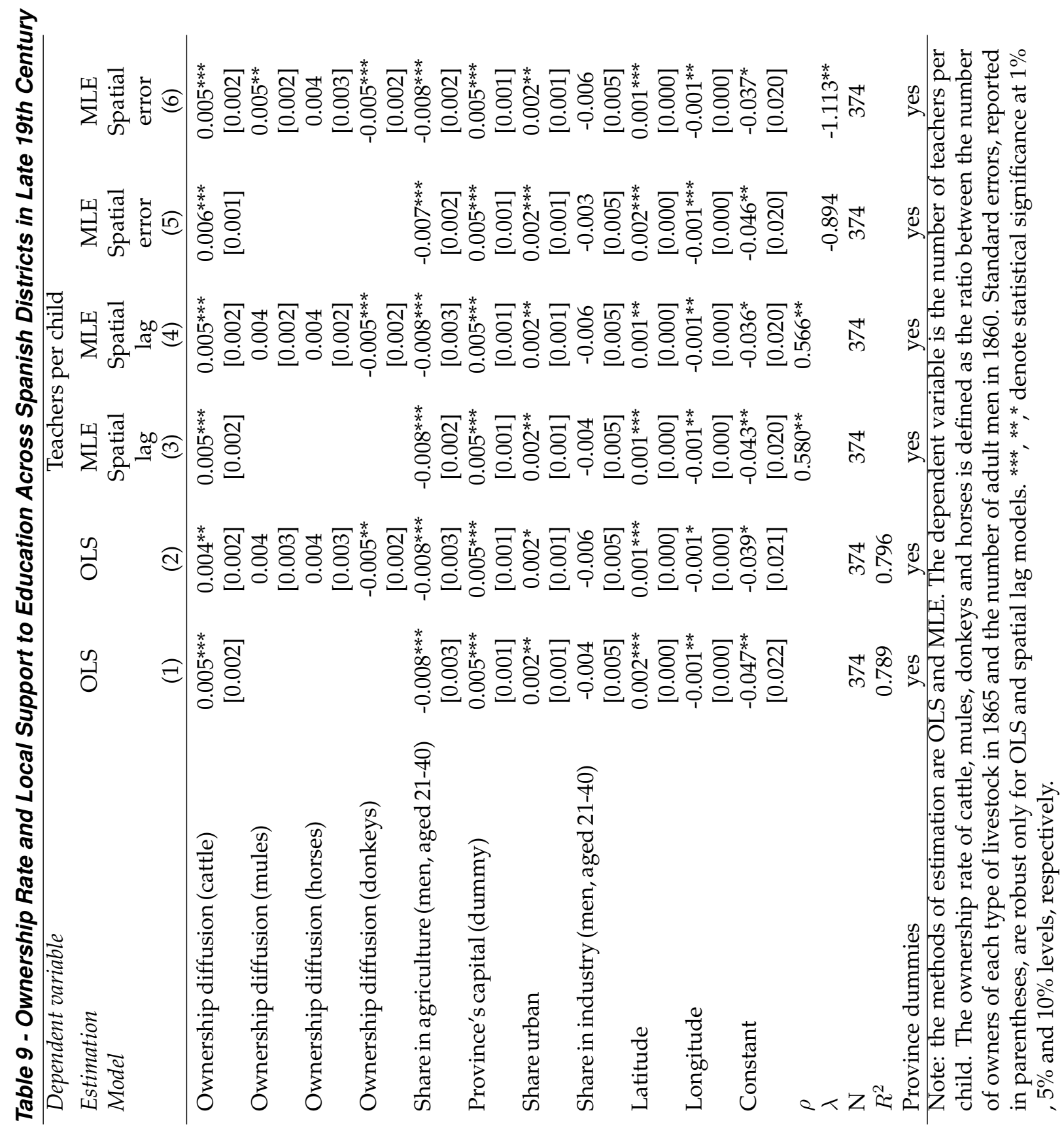


Average mules, donkeys, horses and cattle per owner are 1.9, 1.4, 1.8 and 4.8 units, respectively (see Table 1). Hence, to capture medium-large livestock owners a lower bound of five (Livestock inequality 1 ) or ten (Livestock inequality 2) units is used. Land ownership inequality is measured as the share of land owners with more than 50 hectares of land in 1924. Despite the sixty year gap since 1865, the correlation between this measure and those constructed using livestock owners is high (0.7), as shown in Table 10 and Figure 3.

In addition, we note that the correlation between the ownership rate and the share of medium-large land (or livestock) owners is negative and significant. In fact, in areas where the number of owners is relatively high, we expect a relatively lower share of large owners. Regarding the second aim of our province-level analysis, we start by looking at the simple correlation between ownership rate and inequality measures on the one hand and men's literacy on the other (Figures 4 to 7 ). The main conclusion we draw is that the positive correlation between ownership and literacy rates is higher - and not driven by few outliers - than the negative correlation between ownership inequality and literacy rates.

To further test the relative importance of these different indices we run a horse-race between them using a basic set of controls (Table 11). This horse-race helps us to gauge the relative importance of the demand (captured by the ownership rate) and supply (captured by the Gini index and the share of medium-large owners) channels. The substantial difference in the model's explanatory power across specifications confirms the impression drawn from Figures 4 to 7 . While ownership rates display a strong positive correlation with literacy rates, the inequality measures do not. This result suggests the importance of the demand channel linked to livestock/land ownership: that is, being an owner - independently of the size of the ownership - increased the incentives to acquire human capital in the form of literacy (and/or to promote their acquisition). On the other hand, there is less robust evidence in favour of the supply side channel working through a detrimental effect due to the presence of large livestock/land owners. 
Table 10 - Livestock and Land Ownership Inequality: Province-Level Correlations

\begin{tabular}{lccccc}
\hline & $\begin{array}{c}\text { Land } \\
\text { inequality }\end{array}$ & $\begin{array}{c}\text { Livestock } \\
\text { inequality } 1\end{array}$ & $\begin{array}{c}\text { Livestock } \\
\text { inequality } 2\end{array}$ & $\begin{array}{c}\text { Gini index } \\
\text { (livestock) }\end{array}$ & $\begin{array}{c}\text { Ownership } \\
\text { rate (livestock) }\end{array}$ \\
\hline $\begin{array}{l}\text { Land } \\
\text { inequality }\end{array}$ & 1 & & & & \\
$\begin{array}{l}\text { Livestock } \\
\text { inequality } 1\end{array}$ & $0.744^{* * *}$ & 1 & & & \\
$\begin{array}{l}\text { Livestock } \\
\text { inequality 2 }\end{array}$ & $0.738^{* * *}$ & $0.869^{* * *}$ & 1 & & \\
$\begin{array}{l}\text { Gini index } \\
\text { (livestock) }\end{array}$ & $0.775^{* * *}$ & $0.912^{* * *}$ & $0.897^{* * *}$ & 1 & 1 \\
$\begin{array}{l}\text { Ownership rate } \\
\text { (livestock) }\end{array}$ & $-0.357^{*}$ & $-0.2979^{* *}$ & $-0.412^{* * *}$ & $-0.264^{*}$ & 1 \\
\hline $\begin{array}{l}\text { Note: pairwise correlations are obtained using data on 49 Spanish provinces, with the ex- } \\
\text { ception of those involving land inequality which is available only for 27 provinces. }\end{array}$
\end{tabular}

Figure 3 - Livestock and Land Ownership Inequality

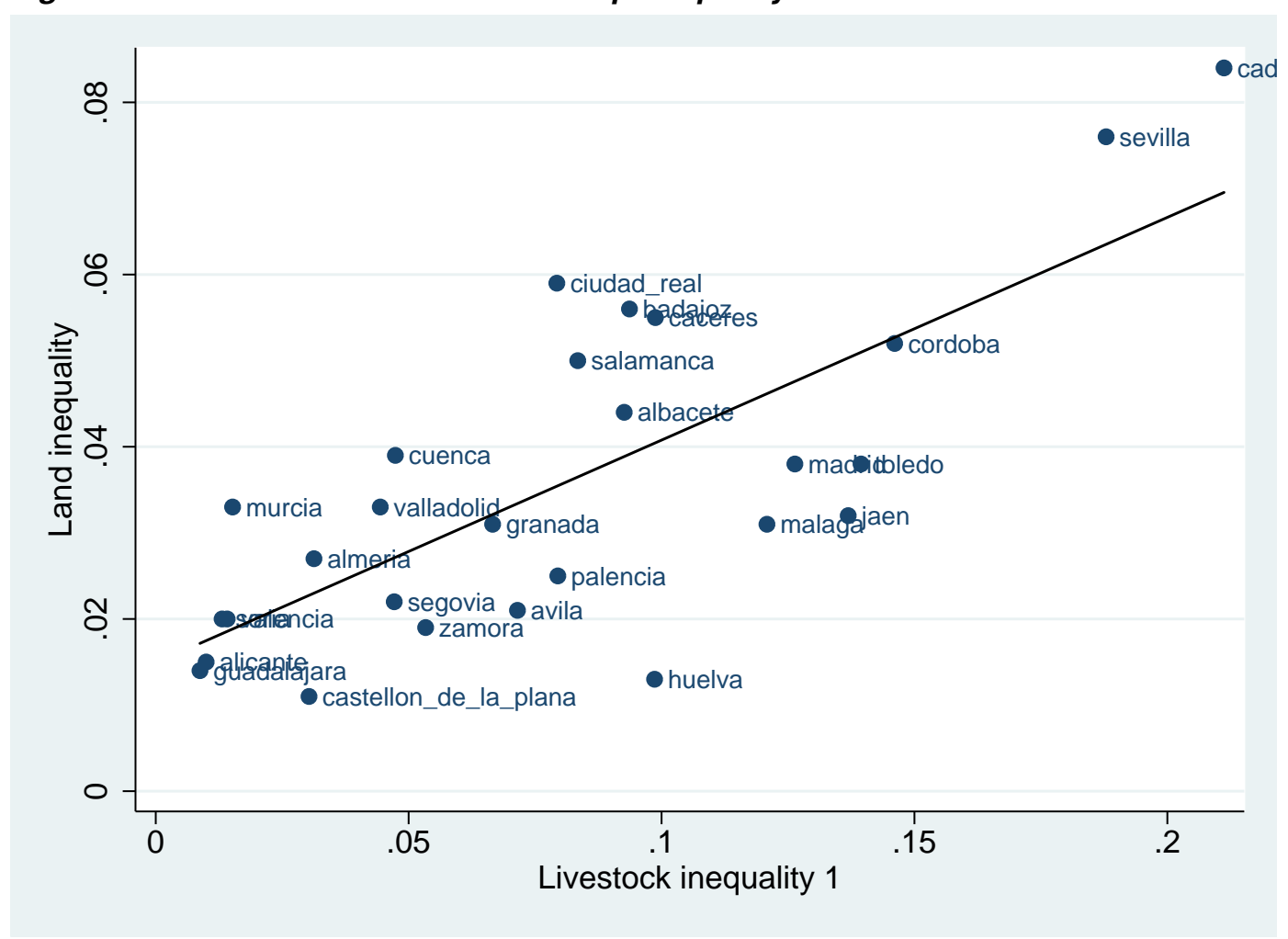


Figure 4 - Ownerhip and Literacy Rates: Province-Level Data

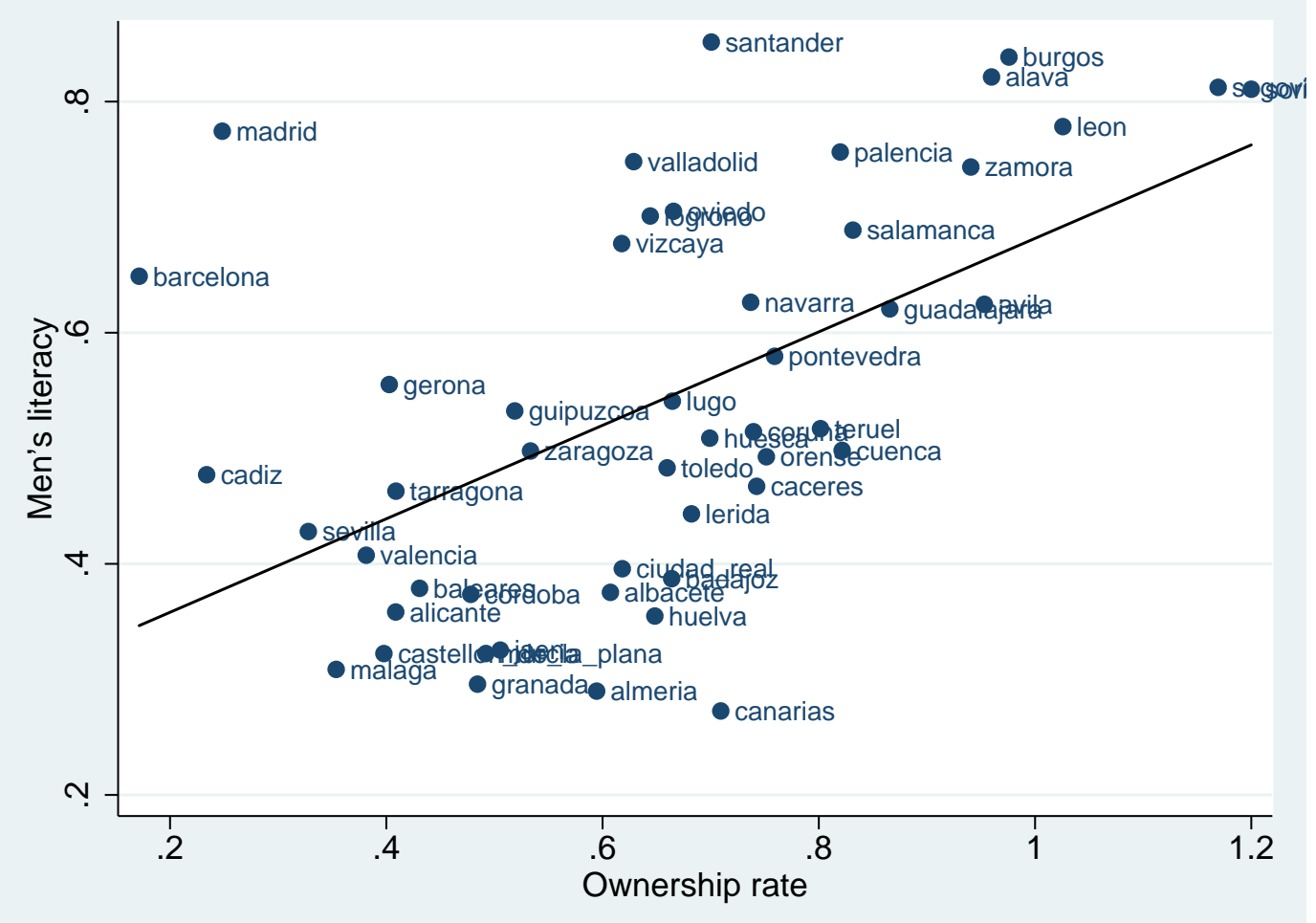

Figure 5 - Livestock Inequality and Literacy: Province-Level Data

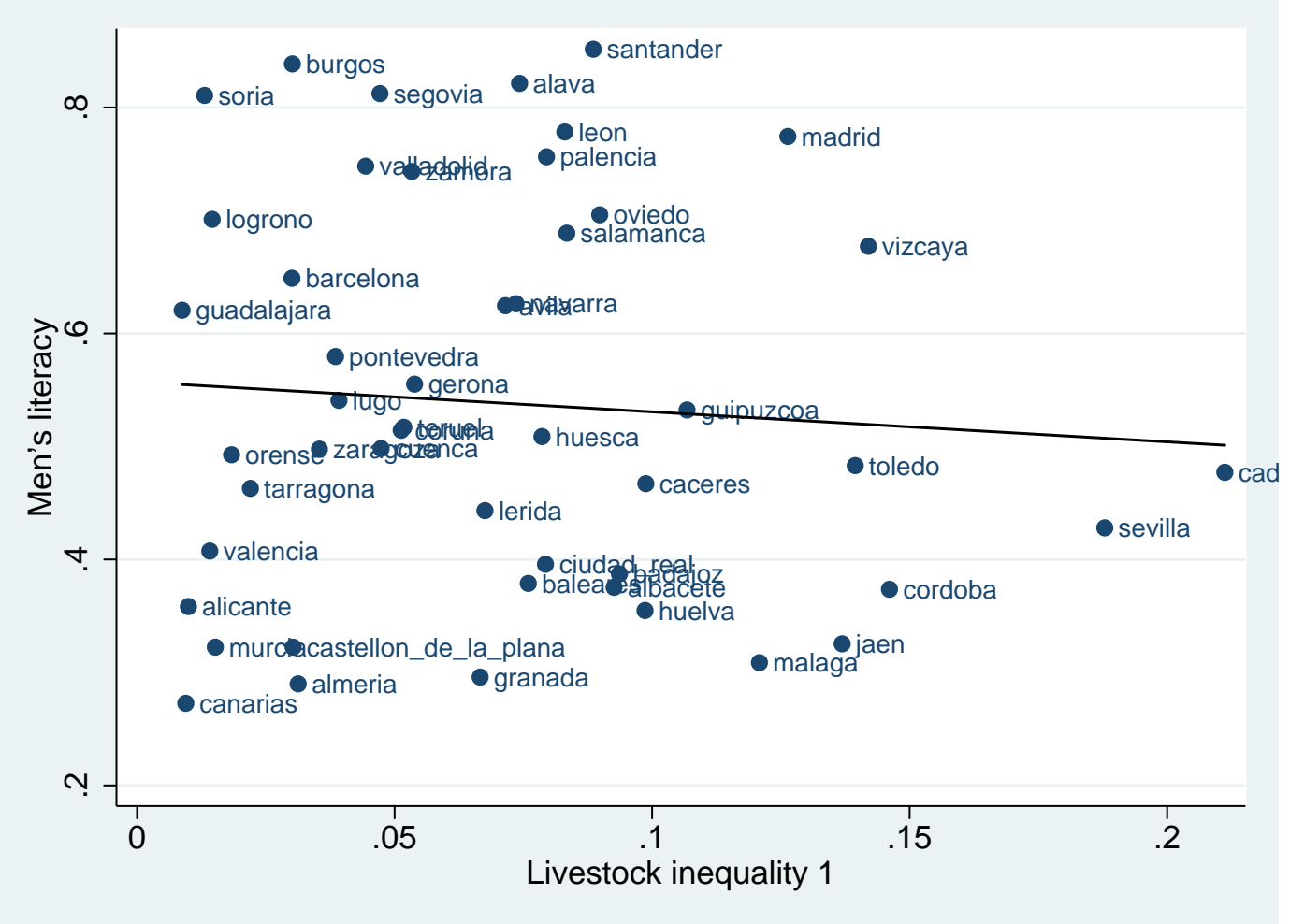


Figure 6 - Livestock Inequality and Literacy: Province-Level Data

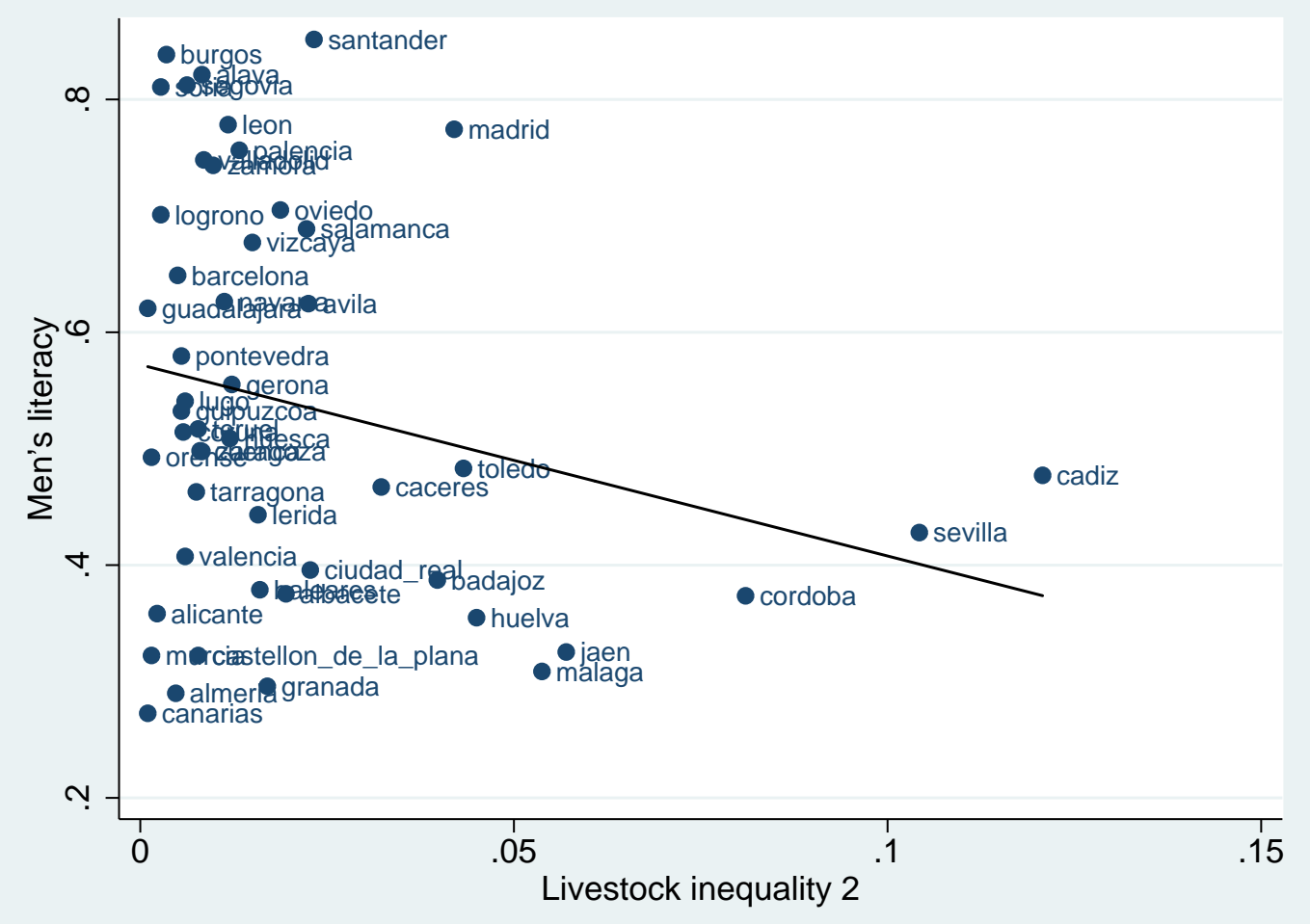

Figure 7 - Livestock Inequality (Gini) and Literacy: Province-Level Data

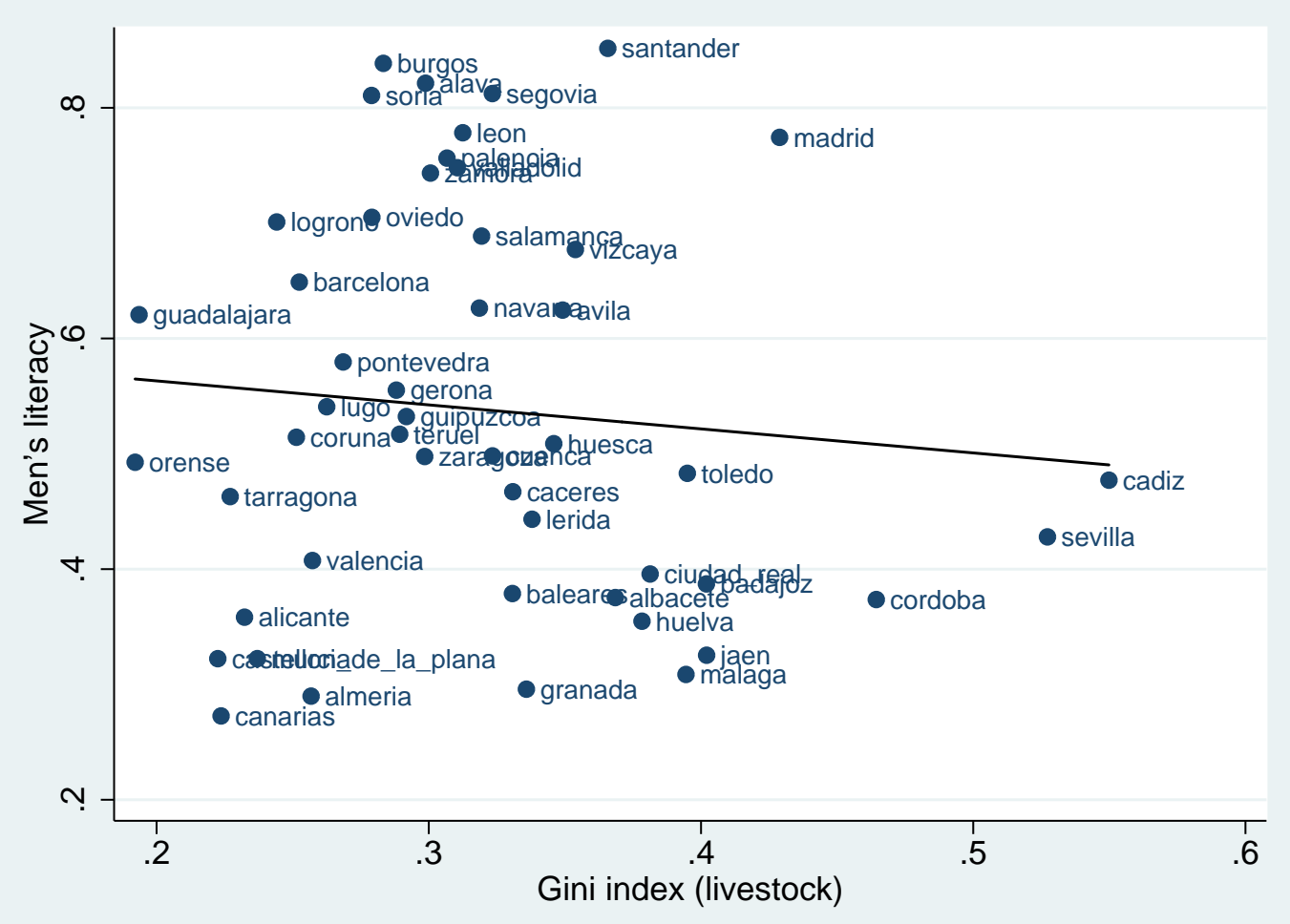




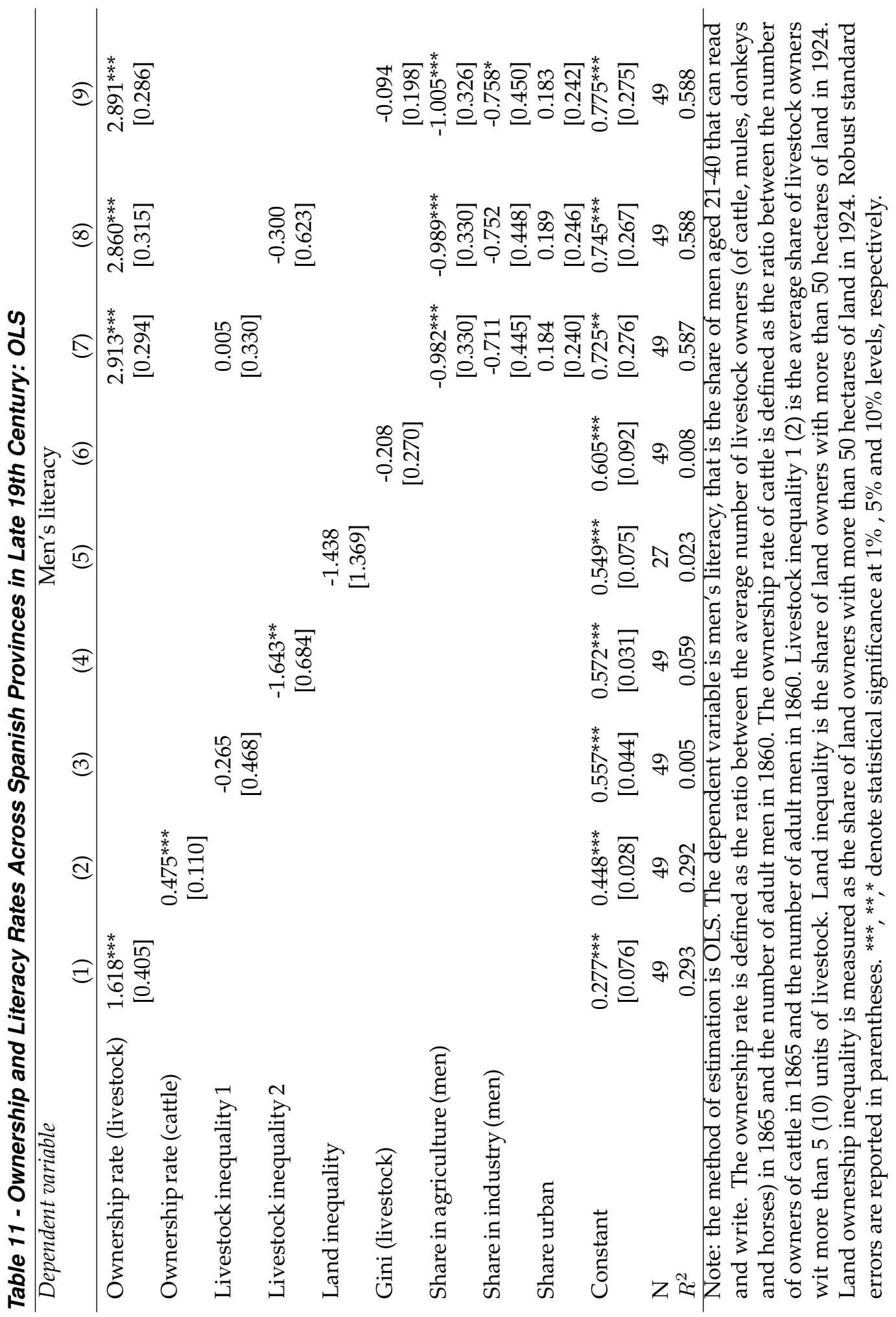

http://www.rei.unipg.it/rei/article/view/121 


\section{Conclusion}

This paper studies the association between ownership structure and literacy across Spanish districts in the late 19th century. We find a strong positive correlation between the ownership rate of the type of livestock mostly used in agriculture and the literacy rate, which is robust to controlling for a large set of potential explanatory factors including spatial effects. Also, ownership of the second type of livestock mostly used in agriculture is positively and significantly correlated with literacy in most regressions. This result suggests that the structure of (livestock/land) ownership was important in shaping literacy rates. In our district level analysis, we cannot distinguish whether this correlation is due to demand and/or supply channels. Using a province-level analysis, we run a horse-race suggesting that the demand-side channel might be more relevant. That is, being a livestock/land owner - independently of the size of the ownership - increased the incentives to acquire human capital in the form of literacy. 


\section{References}

Acemoglu, D., Johnson, S., Robinson, J., 2001. The Colonial Origins of Comparative Development. American Economic Review 91, 1369-1401. doi:10.1257/aer.91.5.1369

Becker, S.O., Cinnirella, F., Woessmann, L., 2010. The Trade-off between Fertility and Education: Evidence from Before the Demographic Transition. Journal of Economic Growth 15, 177-204. doi:10.1007/s10887-010-9054-x

Camps, E., 2003. The Rise and Decline of Children's Participation Levels during the Early Stages of Industrialization. Catalonia (1850-1925). Working Papers 51, Barcelona Graduate School of Economics.

Cinnirella, F. Hornung, E., 2013. Landownership Concentration and the Expansion of Education. CAGE Online Working Paper Series 174, Competitive Advantage in the Global Economy (CAGE).

Easterly, W., Levine, R., 2003. Tropics, Germs, and Crops: The Role of Endowments in Economic Development. Journal of Monetary Economics 50, 3-39. doi:10.1016/S0304-3932(02)00200-3

Easterly, W., 2007. Inequality does Cause Underdevelopment: Insights From a new Instrument. Journal of Development Economics 84, 755-776. doi:10.1016/j.jdeveco.2006.11.002

Galor O., Moav, O., Vollrath, D., 2009. Inequality in Landownership, the Emergence of Human-Capital Promoting Institutions, and the Great Divergence. Review of Economic Studies 76, 143-179. doi:10.1111/j.1467937X.2008.00506.X

Hippe, R., Baten, J., 2012. 'Keep them ignorant?' Did Inequality in Land Distribution delay Regional Numeracy Formation? Mimeo, University of Tuebingen.

Jeanty, P.W., 2010. SPMLREG: Stata Module to Estimate the Spatial Lag, the Spatial Error, the Spatial Durbin, and the General Spatial Models by Maximum Likelihood. Statistical Software Components S457135, Boston College Department of Economics.

Michalopoulos, S., Papaioannou, E., 2013. Pre-Colonial Ethnic Institutions and Contemporary African Development. Econometrica 81, 113-152. doi:10.3982/ECTA9613

Michalopoulos, S., Papaioannou, E., 2014. National Institutions and Subnational Development in Africa. The Quarterly Journal of Economics 129, 151-213. doi:10.1093/qje/qjt0292 
Ministerio de Administraciones Públicas 2008. Variaciones de los municipios de España desde 1842. Secretaría General Técnica. Available at: http://www.seap.mi nhap.gob.es/dms/es/publicaciones/centro_de_publicaciones_de_la_sgt/ Monografias 0/parrafo/011113/text_es_files/Variaciones-INTERNET.pdf

Morrisson, C., Murtin, F., 2009. The Century of Education. Journal of Human Capital 3, 1-42. doi:10.1086/600102

Núñez, C.E., 2005a. Educación. In: Carreras, A. y Tafunell, X. (coords.), Estadísticas históricas de España, siglos XIX y XX. Fundación BBVA, Bilbao, Tomo 1, pp. 155-245.

Núñez, C.E., 2005b. A Modern Human Capital Stock. Spain in the Nineteenth and Twentieth Centuries. In: Jerneck, M., Mörner, M., Tortella, G. y Akerman, S. (eds.), Different Paths to Modernity. A Nordic and Spanish Perspective. Lund: Nordic Academic Press, pp. 122-142.

Pidal, J.C., Rosés, J.R., 2011. Was land reform necessary? Access to Land in Spain, 1860 to 1931. Universidad Carlos III de Madrid Working Papers 11-01.

Sokoloff, K.L., Engerman, S.L., 2000. History Lessons: Institutions, Factors Endowments, and Paths of Development in the New World. The Journal of Economic Perspectives 14, 217-232. doi:10.1257/jep.14.3.217 


\section{Appendix}

Table 12 - Districts Included in the District-Level Analysis

\begin{tabular}{|c|c|c|c|}
\hline District & Province & District & Province \\
\hline Aguilar & Cordoba & Atienza & Guadalajara \\
\hline Alba de tormes & Salamanca & Avila & Avila \\
\hline Albacete & Albacete & Aviles & Oviedo \\
\hline Albaida & Valencia & Ayamonte & Huelva \\
\hline Albarracin & Teruel & Ayora & Valencia \\
\hline Alberique & Valencia & Badajoz & Badajoz \\
\hline Alburquerque & Badajoz & Baena & Cordoba \\
\hline Alcala la real & Jaen & Baeza & Jaen \\
\hline Alcanices & Zamora & Balaguer & Lerida \\
\hline Alcaniz & Teruel & Baltanas & Palencia \\
\hline Alcantara & Caceres & Bande & Orense \\
\hline Alcaraz & Albacete & Barbastro & Huesca \\
\hline Alcazar de san juan & Ciudad real & Baza & Granada \\
\hline Alfaro & Logroño & Becerrea & Lugo \\
\hline Algeciras & Cadiz & Bejar & Salamanca \\
\hline Alhama & Granada & Belchite & Zaragoza \\
\hline Alicante & Alicante & Belmonte & Cuenca \\
\hline Almaden & Ciudad real & Belmonte & Oviedo \\
\hline Almagro & Ciudad real & Belorado & Burgos \\
\hline Almansa & Albacete & Benabarre & Huesca \\
\hline Almazan & Soria & Benavente & Zamora \\
\hline Almendralejo & Badajoz & Berga & Barcelona \\
\hline Almeria & Almeria & Berja & Almeria \\
\hline Almodovar del campo & Ciudad real & Bermillo de sayago & Zamora \\
\hline Almunia de dona godina & Zaragoza & Betanzos & La Coruña \\
\hline Alora & Malaga & Boltana & Huesca \\
\hline Amurrio & Alava & Borja & Zaragoza \\
\hline Antequera & Malaga & Brihuega & Guadalajara \\
\hline Aoiz & Navarra & Bujalance & Cordoba \\
\hline Aracena & Huelva & Burgo de osma & Soria \\
\hline Aranda de duero & Burgos & Burgos & Burgos \\
\hline Archidona & Malaga & Cabra & Cordoba \\
\hline Arcos de la frontera & Cadiz & Cabuerniga & Santander \\
\hline Arenas san pedro & Avila & Caceres & Caceres \\
\hline Arenys de mar & Barcelona & Cadiz & Cadiz \\
\hline Arevalo & Avila & Calahorra & Logroño \\
\hline Arrecife & Canarias & Calamocha & Teruel \\
\hline Arzua & La Coruña & Calatayud & Zaragoza \\
\hline Astorga & Leon & Caldas & Pontevedra \\
\hline Ateca & Zaragoza & Callosa de ensarria & Alicante \\
\hline
\end{tabular}


Table 12 Continued - Districts Included in the District-Level Analysis

\begin{tabular}{|c|c|c|c|}
\hline District & Province & District & Province \\
\hline Cambados & Pontevedra & Denia & Alicante \\
\hline Canete & Cuenca & Don benito & Badajoz \\
\hline Cangas de onis & Oviedo & Ecija & Sevilla \\
\hline Caniza & Pontevedra & Egea de los caballeros & Zaragoza \\
\hline Canjayar & Almeria & Enguera & Valencia \\
\hline Caravaca & Murcia & Estella & Navarra \\
\hline Carballino & Orense & Estepa & Sevilla \\
\hline Carballo & La Coruña & Estrada & Pontevedra \\
\hline Carlet & Valencia & Falset & Tarragona \\
\hline Cartagena & Murcia & Ferrol & La Coruña \\
\hline Casas ibanez & Albacete & Fonsagrada & Lugo \\
\hline Caspe & Zaragoza & Fraga & Huesca \\
\hline Castro del rio & Cordoba & Frechilla & Palencia \\
\hline Castro urdiales & Santander & Fregenal de la sierra & Badajoz \\
\hline Castrogeriz & Burgos & Fuente de cantos & Badajoz \\
\hline Castuera & Badajoz & Fuentesauco & Zamora \\
\hline Cazalla de la sierra & Sevilla & Gandesa & Tarragona \\
\hline Cazorla & Jaen & Garrovillas & Caceres \\
\hline Cebreros & Avila & Gigueras & Gerona \\
\hline Celanova & Orense & Gijon & Oviedo \\
\hline Cervera & Palencia & Ginzo & Orense \\
\hline Cervera & Lerida & Granollers & Barcelona \\
\hline Chantada & Lugo & Grazalema & Cadiz \\
\hline Chelva & Valencia & Guadalajara & Guadalajara \\
\hline Chiclana de la frontera & Cadiz & Guadix & Granada \\
\hline Chinchilla & Albacete & Guia & Canarias \\
\hline Chinchon & Madrid & Haro & Logroño \\
\hline Chiva & Valencia & Herrera del duque & Badajoz \\
\hline Cieza & Murcia & Hijar & Teruel \\
\hline Cifuentes & Guadalajara & Hinojosa duque & Cordoba \\
\hline Ciudad real & Ciudad real & Hoyos & Caceres \\
\hline Ciudad rodrigo & Salamanca & Huelma & Jaen \\
\hline Cogolludo & Guadalajara & Huelva & Huelva \\
\hline Coin & Malaga & Huercal overa & Almeria \\
\hline Colmenar & Malaga & Huesca & Huesca \\
\hline Corcubion & La Coruña & Huescar & Granada \\
\hline Cuellar & Segovia & Huete & Cuenca \\
\hline Cuenca & Cuenca & Ibiza & Baleares \\
\hline Daimiel & Ciudad real & Illescas & Toledo \\
\hline Daroca & Zaragoza & Inca & Baleares \\
\hline
\end{tabular}


Table 12 Continued - Districts Included in the District-Level Analysis

\begin{tabular}{|c|c|c|c|}
\hline District & Province & District & Province \\
\hline Infantes & Ciudad real & Medina del campo & Valladolid \\
\hline Iznalloz & Granada & Medina sidonia & Cadiz \\
\hline Jaca & Huesca & Medinaceli & Soria \\
\hline Jaen & Jaen & Mellin & Albacete \\
\hline Jarandilla & Caceres & Merida & Badajoz \\
\hline Jativa & Valencia & Miranda de ebro & Burgos \\
\hline Jerez de la frontera & Cadiz & Molina & Guadalajara \\
\hline Jerez de los caballeros & Badajoz & Mondonedo & Lugo \\
\hline Jijona & Alicante & Monforte & Lugo \\
\hline La Coruña & La Coruña & Monovar & Alicante \\
\hline La baneza & Leon & Montalban & Teruel \\
\hline La carolina & Jaen & Montanchez & Caceres \\
\hline Laguardia & Alava & Montblanch & Tarragona \\
\hline Laguna & Canarias & Montefrio & Granada \\
\hline Lalin & Pontevedra & Montilla & Cordoba \\
\hline Laredo & Santander & Montoro & Cordoba \\
\hline Laroda & Albacete & Moron & Sevilla \\
\hline Ledesma & Salamanca & Motilla del palancar & Cuenca \\
\hline Lena & Oviedo & Motril & Granada \\
\hline Leon & Leon & Mula & Murcia \\
\hline Lerida & Lerida & Murcia & Murcia \\
\hline Lerma & Burgos & Murias de paredes & Leon \\
\hline Lillo & Toledo & Muros & La Coruña \\
\hline Llanes & Oviedo & Najera & Logroño \\
\hline Llerena & Badajoz & Nava del rey & Valladolid \\
\hline Logrono & Logroño & Navahermosa & Toledo \\
\hline Loja & Granada & Navalmoral de la mata & Caceres \\
\hline Lora del rio & Sevilla & Negreira & La Coruña \\
\hline Lorca & Murcia & Novelda & Alicante \\
\hline Luarca & Oviedo & Noya & La Coruña \\
\hline Lucena & Cordoba & Ocana & Toledo \\
\hline Lugo & Lugo & Olivenza & Badajoz \\
\hline Madridejos & Toledo & Olmedo & Valladolid \\
\hline Mahon & Baleares & Olot & Gerona \\
\hline Malaga & Malaga & Olvera & Cadiz \\
\hline Manacor & Baleares & Onteniente & Valencia \\
\hline Manzanares & Ciudad real & Orcera & Jaen \\
\hline Marbella & Malaga & Ordenes & La Coruña \\
\hline Marchena & Sevilla & Orgaz & $\begin{array}{l}\text { Toledo } \\
\text { Tolo }\end{array}$ \\
\hline Mataro & Barcelona & Orihuela & Alicante \\
\hline
\end{tabular}


Table 12 Continued - Districts Included in the District-Level Analysis

\begin{tabular}{|c|c|c|c|}
\hline District & Province & District & Province \\
\hline Orotava & Canarias & Roa & Burgos \\
\hline Ortigueira & La Coruña & Rute & Cordoba \\
\hline Osuna & Sevilla & S. domingo de la calzada & Logroño \\
\hline Padron & La Coruña & Sacedon & Guadalajara \\
\hline Palma & Baleares & Sahagun & Leon \\
\hline Palmas & Canarias & Saldana & Palencia \\
\hline Pamplona & Navarra & San clemente & Cuenca \\
\hline Pastrana & Guadalajara & San felio de llobregat & Barcelona \\
\hline Pego & Alicante & San roque & Cadiz \\
\hline Penafiel & Valladolid & San sebastian & Guipuzcoa \\
\hline Piedrabuena & Ciudad real & San vicente de la barquera & Santander \\
\hline Pina & Zaragoza & Sanlucar de barrameda & Cadiz \\
\hline Ponferrada & Leon & Sanlucar la mayor & Sevilla \\
\hline Pontevedra & Pontevedra & Santa cruz de la palma & Canarias \\
\hline Posadas & Cordoba & Santa cruz de tenerife & Canarias \\
\hline Potes & Santander & Santa maria de nieva & Segovia \\
\hline Pozoblanco & Cordoba & Santafe & Granada \\
\hline Priego & Cuenca & Santander & Santander \\
\hline Priego de cordoba & Cordoba & Santiago & La Coruña \\
\hline Puebla de alcocer & Badajoz & Santona & Santander \\
\hline Puebla de sanabria & Zamora & Sarinena & Huesca \\
\hline Puebla de trives & Orense & Sarria & Lugo \\
\hline Puente del arzobispo & Toledo & Sedano & Burgos \\
\hline Puenteareas & Pontevedra & Segovia & Segovia \\
\hline Puentedeume & La Coruña & Seo de urgel & Lerida \\
\hline Puigcerda & Gerona & Sepulveda & Segovia \\
\hline Punte cadelas & Pontevedra & Sequeros & Salamanca \\
\hline Purchena & Almeria & Sevilla & Sevilla \\
\hline Quintanar de la orden & Toledo & Siguenza & Guadalajara \\
\hline Quiroga & Lugo & Solsona & Lerida \\
\hline Ramales & Santander & Sort & Lerida \\
\hline Rambla & Cordoba & Sos & Zaragoza \\
\hline Redondela & Pontevedra & Sueca & Valencia \\
\hline Reinosa & Santander & Tafalla & Navarra \\
\hline Requena & Valencia & Talavera de la reina & Toledo \\
\hline Reus & Tarragona & Tamarite & Huesca \\
\hline Riano & Leon & Tarancon & Cuenca \\
\hline Riaza & Segovia & Tarazona & Zaragoza \\
\hline Ribadavia & Orense & Tarragona & Tarragona \\
\hline Ribadeo & Lugo & Teruel & Teruel \\
\hline
\end{tabular}


Table 12 Continued - Districts Included in the District-Level Analysis

\begin{tabular}{llll}
\hline District & Province & District & Province \\
\hline Toledo & Toledo & Villar del arzobispo & Valencia \\
Toro & Zamora & Villarcayo & Burgos \\
Torrecilla en cameros & Logroño & Villaviciosa & Oviedo \\
Torrelaguna & Madrid & Villena & Alicante \\
Torrelavega & Santander & Vinaroz & Castellon \\
Torrox & Malaga & Vitigudino & Salamanca \\
Tortosa & Tarragona & Vitoria & Alava \\
Totana & Murcia & Viver & Castellon \\
Tremp & Lerida & Vivero & Lugo \\
Tudela & Navarra & Yecla & Murcia \\
Tuy & Pontevedra & Yeste & Albacete \\
Valdeorras & Orense & Zafra & Badajoz \\
Valdepenas & Ciudad real & Zamora & Zamora \\
Valderrobres & Teruel & Zaragoza & Zaragoza \\
Valencia de alcantara & Caceres & & \\
Valencia de don juan & Leon & & \\
Valladolid & Valladolid & & \\
Valls & Tarragona & & \\
Valoria la buena & Valladolid & & \\
Valverde del camino & Huelva & & \\
Vecilla & Leon & & \\
Velez malaga & Malaga & & \\
Velez rubio & Almeria & & \\
Vendrell & Tarragona & & \\
Vera & Almeria & & \\
Vergara & Guipuzcoa & & \\
Verin & Orense & \\
Viana & Orense & & \\
Vich & Barcelona & & \\
Viella & Lerida & & \\
Vigo & Pontevedra & & \\
Villacarriedo & Santander & & \\
Villacarrillo & Jaen & & \\
Villadiego & Burgos & & \\
Villafranca del bierzo & Leon & & \\
Villajoyosa & Alicante & & \\
Villalba & Lugo & & \\
Villalon & Valladolid & & \\
Villalpando & Zamora & & \\
Villanueva de la serena & Badajoz & & \\
\hline & & & \\
\hline & & \\
& & \\
\hline
\end{tabular}

